\title{
Public Service: Social Factors in the Architecture of F.H. Newman
}

\author{
ANDREW LEACH \\ Wellington Institute of Technology
}

Individual archives contain but fragments of collective knowledge, potential evidence for the historian of any discipline. In turn, architectural history confronts the analyst with accounts that, while not conflicting, sometimes overlook the nuances underscoring the range of design decisions in architectural activity. On a spectrum defined at one end by the occasionally bare bones of official documentation, housed in official repositories, and at the other by the personally-held beliefs of the architect, often read simply in the isolated terms of architectural discourse, these accounts sit. Yet the architect's individuality must inflect the official programme as surely as the reverse is true. Proposing the particularities of that balance becomes one task of the architectural historian.

This essay introduces the thinking of a New Zealand public service architect: Frederick Hugh Newman (1900-1964). Newman's ideas, archived in writings and lectures produced from the mid-1940s to the early-1960s, strongly describe issues and concerns Newman saw as influencing the work that he and his colleagues were engaged in. This, on its own, must interest any student of New Zealand's architectural history. Upon discovery that Newman's ideas emerged from a cosmopolitan and continental professional life - a career including socialist housing in 1920s Vienna, the development of Soviet infrastructure in the 1930s, the abandonment of 'culture' associated with the Third Reich, and professional relationships with 'opposite numbers' in London, Paris and Rome - his insights assume an international significance. Understanding Newman's place in those settings legitimates a proposal that the experiences of an émigré working in Wellington afford insights into the mechanisms of modern architecture's international diffusion. It further lifts a veil of anonymity draped over individual contributions to Government architecture and offers a model for future researches into this extraordinary period.

In a traditional sense, while public history pursues questions of the changing nature of society and its agencies, architectural history interrogates ideas driving the development of building across time. That the latter, with its stylistic and theoretical underpinnings, may become evidential for the 
former, privileging documentation, is a little-tested idea. This essay aims primarily to identify the importance of the individual's role in public service. The essays and images that follow tread the territory between Newman's thinking as committed to paper, the sources that prompted such thoughts, and architectural projects that demonstrate or coincide with his printed visions. These archival remnants backdrop significant years in New Zealand's twentieth century, making clear the important contribution of European migrants to New Zealand's architectural and intellectual history. ${ }^{1}$

\section{The First Forty Years: Vienna (1900-24, 27-31, 37-38), Paris (1924-1927), Moscow (1931-37)}

Frederick Hugh Newman was born Friedrich Hugo Neumann in Vienna in $1900 .^{2}$ His parents, Hedwig Neumann-Pisling and Alexander Neumann ('very strong minded and able individuals'3), respectively practiced painting and architecture. He studied architecture at his father's alma mater, the Wien Technische Hochschule, following his father's course as an IngeneurArchitekt, graduating in 1923. This is where many obvious similarities between the two architects terminate. Although the younger Neumann's early career followed the beaux-arts models established within his educational context, work from his senior studies indicates changed values in both the social and architectural senses. These signalled probable further changes as Friedrich Neumann engaged with specifically socialist projects, and produced architecture that clearly referenced this socialist influence in Viennese terms. In contrast, the elder Alexander Neumann was raised in Imperial Vienna, practiced beaux-arts architecture with teeth cut on the grandest products of the Fellner and Helmer theatre design practice. In 1939 Alexander Neumann brought to New Zealand a number of drawings from this practice, these demonstrating the work he had contributed to the partnership as a student in the early 1880 s and later as studio head in the early 1890 s. $^{4}$

Although modern architecture had found a sure footing in Vienna in the early twentieth century, Alexander Neumann (in collaboration with Ernst von Gotthilf) produced authoritative buildings and interiors for banks, fine homes, and office buildings that did not visibly address such new ideas. ${ }^{5}$ He produced a substantial body of work for the banking house Wiener Bankverein, evidenced through a small number of watercolour renderings of banks in exotic locations, some detail drawings on transparencies (delicately, and now permanently, folded into place in the small Newman collection), and a small book published by the Bank. In short, Alexander Neumann's career was substantial; his receipt of a knighthood in the Order of Franz Joseph in 1913 further marks its importance. The influence of the elder Neumann's architectural practice in his immediate context reinforced 
the necessity of high professional standards for his son, providing a daunting career model that Friedrich Neumann addressed first by taking work in his father's office.

The potential ideological conflict which emerges from a surface reading of the two architects' interests was resolved in part by Alexander Neumann's own subtle pursuit of modern ideas, although seemingly untested against the modernist architectural language of his younger contemporaries Adolf Loos and Joseph Hoffmann. The elder Neumann maintained an architectural practice catering for a strong society and institutional clientele, designing in accordance with new concepts of space and composition, but outwardly

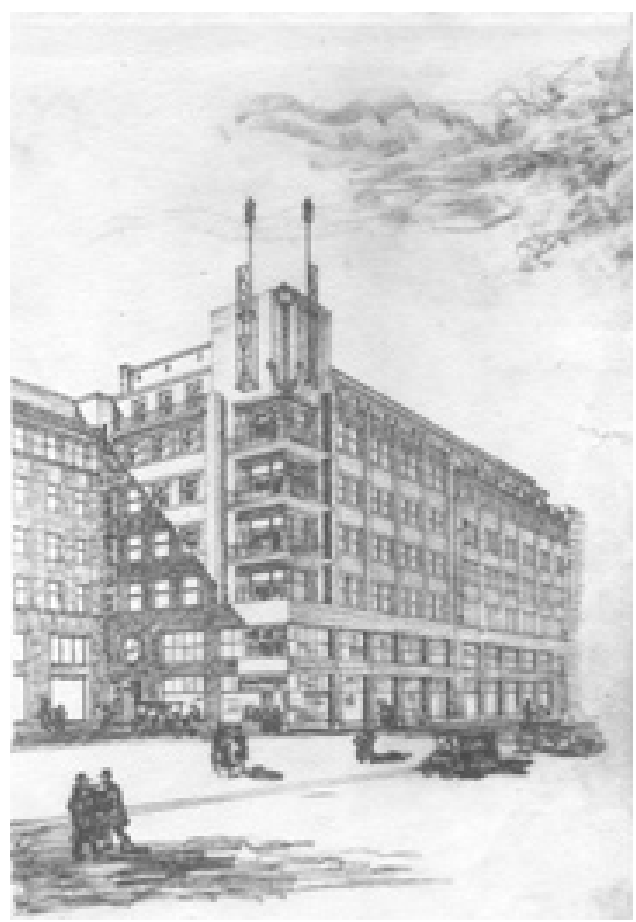

Source: Newman family

Kotva Building, Prague, Neumann und von Gotthilf (F.H. Newman, architect), c.1930. maintaining the ornamental trappings so strongly rejected by Loos. Glimpses of a modern sensibility in his later work invite the consideration of his work as modern, if not directly in the sense associated with the architectural modern movement. Indeed, one of Friedrich Neumann's most striking preWar buildings - the Kotva office building in Prague - came out of the Neumann and von Gotthilf partnership around 1930. This building is an excellent example of Friedrich Neumann's modernism, and an immediate precursor to his large-scale modern architecture in the Soviet Union from 1932. Friedrich Neumann spent two periods working with his father's practice: for about one year immediately following graduation, and between 1927 and 1931.

Between these periods, from 1924 to 1927, Friedrich Neumann studied at the École Supérieure des Beaux-Arts in Paris. Under the supervision of Camille Lefèvre, architect to the Louvre, Neumann was kept busy: a house in Madrid (Villa Velasquez, the only trace of which is a newspaper 
clipping); remodelling work on the Louvre; drawings towards the Palace for the League of Nations in Geneva. This last project came to Lefèvre's office by means of a competition now famous because it was not won by Le Corbusier, leading directly to the formation of the Congrès internationaux de l'architecture moderne. Not one of the 377 entries pleased the architectural jury, and the competition organisers therefore awarded the project to five architects conjointly: Henri-Paul Nénon of France and Julien Flegenheimer of Switzerland, whose designs led the competition, were instructed to collaborate with Carlo Broggi of Italy, Joseph Vágó of Hungary, and Lefèvre. ${ }^{6}$ A single photograph of the primary elevation marked this project in Neumann's résumé. He returned to Vienna in 1927, but with experience on ideologically significant design projects in hand.

For both Neumanns, 1920s Vienna was a city recovering from a dramatic 1918 change of states; almost overnight, it was no longer the seat of an empire, instead the capital of a federal republic. While during these years Austria was politically conservative, Vienna maintained a socialist majority from 1920 to 1933 , effectively operating as a 'state within a state'? The politics of post-World War One Vienna had direct architectural consequences: 'housing passed almost totally into the hands of the public authority', between 5,000 and 30,000 new apartments being built annually between 1923 and $1934 .{ }^{8}$ This socialist programme, initiated by Otto Bauer in 1918, valued housing as 'a social good', but also believed in developing its secondary function as an agent of industrial renewal. Manfredo Tafuri has observed that such a confluence of social utopianism and industrialisation in the context of housing production made 'any attempt at industrialisation in the building trades totally utopian'. ${ }^{9}$ In such a setting, Neumann returned from Paris to an environment of plentiful work within an architectural profession coloured by progressive politics. For five years after his return, until 1932, he designed new housing blocks and social facilities. His references indicate seven residential projects attributable to him from these years, including several residences and Wohnhausanlage: Auhofstrasse 161 (Vienna XIII), Penzingerstrasse 1 (XIII), Spitalgasse 984 (IX), Villa Rosenthal at Peter Jordanstrasse 49 (XIX), and Villa Kuffner on Blaasstrasse (XIX). ${ }^{10}$ Neumann, of course, was only one of many involved in such work. Tafuri suggests that the absolute concentration on housing issues during this time resulted in a general failure of Marxist reform; certainly, the energy applied to this single sector did not feed into other social or architectural programmes. ${ }^{11}$

From 1932, many architects and planners drawn to the idea of a socialist city, many of whom had also made an ideological investment in 'red Vienna', followed the German architect and planner Ernst May to Moscow. They were drawn to the Soviet Union by the opportunity to participate in the design 
of new cities and infrastructure under Stalin's five-year plans. The Austrian contingent saw an opportunity to realise in that country what had proven too difficult in the post-Empire context of Vienna. Friedrich Neumann travelled to Moscow with his wife (Hildegarde, a social worker) in $1932,{ }^{12}$ working as a senior design architect until 1937. The first two five-year plans generated 354 new cities, conceived as a means of anchoring down a transient postrevolution population. The new cities, in the course of their construction, turned farm workers into builders, transforming a peasant world into a modern world of socialist workers. Neumann's projects firmly celebrated the worker with trade union complexes and infrastructural facilities such as hospitals and sanatoria. They included: the Trade Union Building of the Locomotive Factory in Orsk; the Central Trade Unions Council Workers' Club in Theodesia, Crimea; the Railway Works Main Entrance Buildings in Kusnetzk, Siberia; the Main Entrance Buildings for the Copper Refineries in Balkash, Middle Asia; and the Main Entrance Buildings for the 'Stalin' Motorcar Works in Moscow. While the ideology of this programme was complex, the underdeveloped building construction sector prevented complete realisation of Stalin's programme in the short time allowed; the building industry was itself evolving in response to Stalin's plans and had not the maturity to support a socialist building programme in its own terms. A shift in Soviet socialist policy foiled the long-term success of the German and Austrian cultural exchange with Moscow. Just as ideologically displaced foreign specialists, distanced from their own lands, arrived to celebrate the worker, the Soviet State was 'replacing its ideology of work with the new idea of socialist man'. ${ }^{13}$ Many of the Europeans who had sought to realise in a new context what was not possible in Vienna, Berlin or Frankfurt, consequently left the USSR, disillusioned. Among them, Neumann returned to architectural practice in Vienna.

Yet his return to Vienna was short-lived. As fascist and anti-Semite Germany flexed its muscles, Friedrich Neumann and Hildegarde, along with their young daughter Maria, applied 'for the grant of permission to leave for the purpose of emigration to the town of Bogotá in Columbia'. ${ }^{14}$ A visa allowed them to make their way west via Paris to London and Hampstead in England, where friends helped the Neumann's arrange and receive entry with refugee status to New Zealand. The elder Neumanns also made their way to New Zealand, leaving later and travelling via Switzerland.

\section{Transition: Neumann in New Zealand}

In July 1938, Neumann contacted Arthur Tyndall, New Zealand's Director of Housing Construction, to ascertain the possibility of public sector architectural work. While in his reply, dated August 1938, Tyndall stated that 'at present my Department is short of architectural draughtsmen', he added 
that within a short time 'there will be a general election in this country which may affect the Department's programme'. Securing permission to emigrate, the extended Neumann family arrived to Wellington in January 1939. The following month Friedrich Newman accepted a position as 'draughtsman' in the Department of Housing Construction..$^{15}$ However, European architectural qualifications were then (indeed continue to be) unrecognised by the New Zealand architectural registration authorities for local professional practice. Understandably, Neumann, nearly forty and having worked on large-scale and high-profile projects, took offence at the New Zealand professional body's failure to recognise his credentials. Yet his determination to continue working as an architect, rather than as a draughtsman, saw him sit and pass the examinations of the Royal Institute of British Architects in 1947, this allowing him immediate reciprocal membership of the New Zealand Institute of Architects. Anecdotal evidence suggests that many of the numerous European architects who migrated to New Zealand chose to

Maclean Flats, Wellington, Department of Housing Construction (F.H. Newman, architect), 1943-45.

Photo: F.H. Newman. Source: Newman family

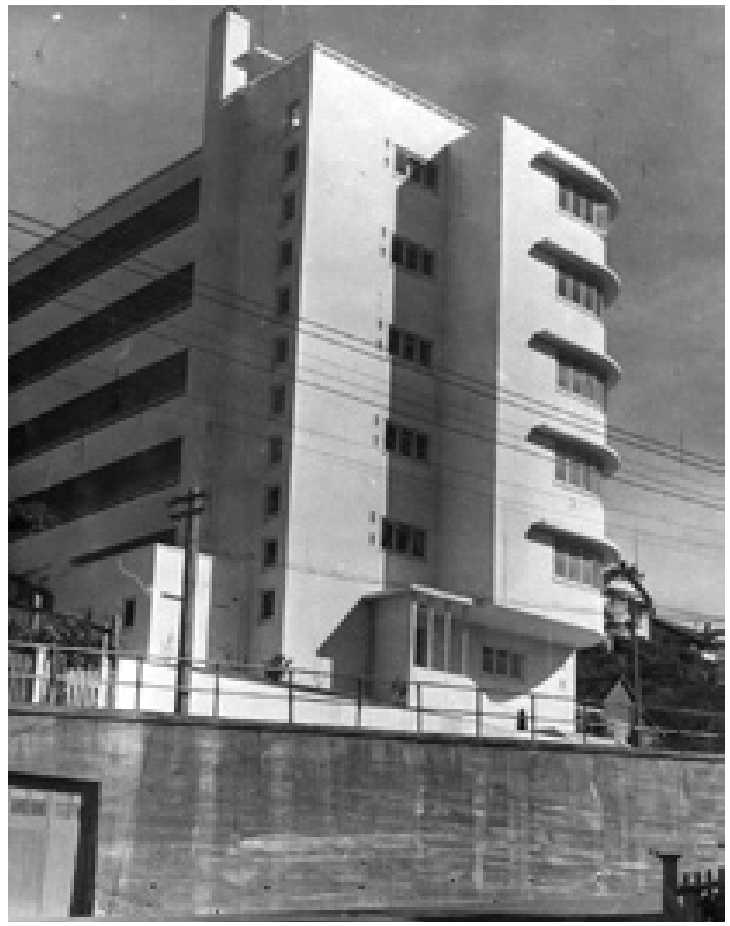

register in this way, rather than by working directly through the local Institute. By this time, under the close supervision of the Department's chief architect, Gordon Wilson, Neumann had produced the bulk of the working drawings for the McLean Flats in Wellington (1943-45). Still under Wilson's authority, but with significantly more autonomy, he had also designed the Symonds Street Flats (1942-1947). ${ }^{16}$

Although Neumann had left the Soviet Union disappointed by the realities of a communist government, he nonetheless still harboured strong 
socialist ideals; he brought these to bear on the position of the architectural profession in New Zealand society. The notion of New Zealand as a field for ideological experimentation was to be substantially realised through Government housing projects and infrastructural development, both drawing on Neumann's architectural and social interests. John A. Lee's Socialism in New Zealand, published in 1938, indexes an international perception of New Zealand as a socialist country operating under a democratic government model. Its author was Under-Secretary to the New Zealand Minister of Finance and responsible for Housing between 1936 and 1939. While the text was available in London during Neumann's stay, and a first edition copy sat (sits) on his bookshelf, there is no certainty that he read the book while in London, nor indeed any direct indicator that it influenced his decision to migrate to New Zealand, or his application for work in the Department of Housing Construction. However, it appears that Britons perceived that the values espoused in Lee's book were widely demonstrated in New Zealand following the Labour Government's election in 1935. In his introduction to Socialism in New Zealand, then British Labour Party leader Clement Attlee wrote: 'We in this country have for many years regarded New Zealand as a laboratory of social experiment. ${ }^{17}$ Attlee characterized the perceived advances as 'the result of a commonsense endeavour to bring society into conformity with social justice', commending the 'concurrent development of the wealth of the community and of measures to ensure a more equitable distribution of purchasing power.'. ${ }^{18}$

Lee celebrated a brand of socialism that, while bearing its share of rhetoric, was nevertheless more driven by pragmatic concerns than ideology. The scope of his text was broad, but maintained a realistic edge, dealing in turn with Government intervention in a range of sectors with increased prosperity as a consequence: banking and financial institutions, overseas trade and internal price guarantees on basic commodities, agriculture, infrastructure, communications, social security, education, health, housing, insurance, and manufacturing industries. Lee wrote: 'In New Zealand there is capitalist ownership of a very large proportion of the machinery of production, and that machinery functions to produce a higher level of existence than Socialist Russia yet knows'. ${ }^{19}$ The issue for him was not whether socialism would underpin the future of New Zealand society, rather whether that socialism would be democratic or dictated. Lee's deeply rooted preference was clearly for the former: 'If New Zealand succeeds in awakening humans as well as in improving their power to acquire goods, New Zealand may become the common man's political Utopia'. ${ }^{20}$ He overconfidently predicted a Labour Government lasting close to twenty years. Neumann may thus have applied for work 
under the Labour Government's housing programme in the hope that his opportunities would be wider and of longer duration than in either Vienna or Moscow.

Neumann, ever acutely politically conscious, was of common mind with many of Lee's views on the form of social equality that a discrete society could implement. A cultured intellectual, he took seriously his own responsibility to uphold values of social morality and equity within New Zealand society. Settled in Wellington, he befriended the youthful Leslie Lipson, founding professor of political science at Victoria University College. Social ideology was undoubtedly discussed on their numerous fishing trips. Moreover, while Lipson was working on The Politics of Equality, ${ }^{21}$ Neumann wrote a short essay entitled 'A Moral Approach to Social Order'. Although the latter was never published, a draft bears an acknowledgement to Lipson's criticism and assistance. Neumann's 'Moral Approach' signalled his disillusionment with current directions in the Soviet Union: 'Never in human history has an economic idea alone received any betterment or appreciable changes of spiritual, philosophical or political views'. ${ }^{22}$ He decried harmful measures of 'economic control,' suggesting 'only a solution which will preserve enterprise fully and uncompromisingly will be successful . . . No moral justification can be given of the present levels of income in the industrially developed countries'. ${ }^{23}$ Neumann argues in favour of 'morally determined' maximum earning capacities for individuals, for the restriction of interest by 'moral principles', and for a generally heightened social and moral education led by the country's schools and universities. ${ }^{24}$

Like many European refugees who arrived in the summer of 1938-39, Neumann embraced the opportunities his new home offered, but did not turn his back on his native culture: 'The [Neumann] home, when you entered it, took you into Vienna, as it was before World War Two and the Nazis. The atmosphere was that of the Viennese culture, with its exquisite taste in art, in music, and in the amenities of a civilised and sophisticated way of living. ${ }^{25}$ In balancing his enthusiasm for new opportunities as an architect in New Zealand with the knowledge that his experience elsewhere had direct relevance for those opportunities, Neumann persisted with European culture, thus continuing the traditions of his earlier life in a vastly different setting.

\section{Neumann to Newman: Architecture in Hydro Design}

During 1947 Neumann registered as an architect, at about the same time anglicising his name to Frederick Hugh Newman and naturalising, along with his immediate family, as a New Zealander. The following year saw the consolidation of the Public Works Department and Department of Housing Construction into the Ministry of Works, with all design and construction responsibilities previously housed in other government departments 
centralised under the new Ministry. From this point, Newman came directly under the authority of the Government Architect (as opposed to the Director of Housing Construction), but he was immediately seconded as Section Head (Architectural) to the Hydro Design Office, a hybrid working group staffed mainly by civil and electrical engineers previously employed by the State Hydro-Electric Department. This office borrowed practices freely from the Tennessee Valley Authority of Franklin Roosevelt's New Deal. There, projects mainly concerned with engineering problems incorporated architects into the design teams. The particular role of the architect in such a setting intrigued Newman, particularly given two added dimensions: the dependence of New Zealand on electrification as a vehicle for modernisation, and the widespread advocacy, following Lenin, of the value of electrification to socialist societies. ${ }^{26}$

Newman's first power station design was Maraetai, on the Waikato River. In his short text 'Beauty in Engineering' (1952), Newman reflects: 'There is much matter for thought in these gigantic projects besides their engineering functions and problems which in themselves are of a magnitude without parallel in New Zealand. Our engineers are proud of their work, and rightly so. But is it only the material side of their designs they are proud of? Does one only think of kilowatts when confronted with such engineering works? ${ }^{27} \mathrm{He}$ was conscious of the value the New Zealand public placed on these projects. The hydroelectricity programme - which, for Newman, included power station projects at Cobb River, Whakamaru and Roxburgh, as well as substations at Haywards, Islington, and Papanui

Maraetai Hydro-Electric Power Station, Waikato River, Hydro Design Group, Ministry of Works (F.H. Newman, Housing Architect), 1946-1953.

Photo: F.H. Newman, c.1953. Source: Newman family

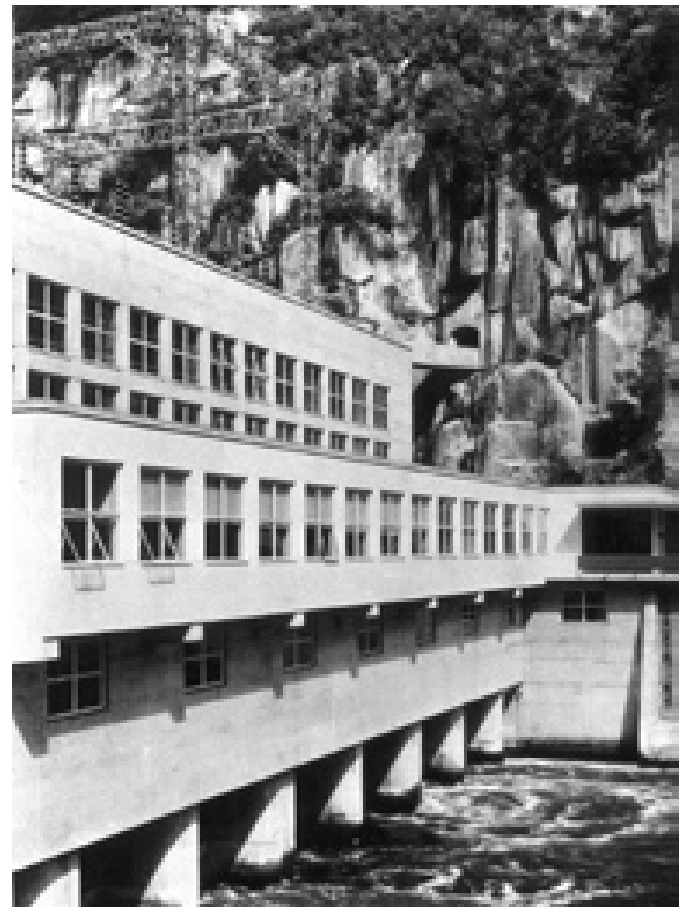


- allowed the pursuit of both the communicative and social function of public architecture: 'The national importance of these large structures must, I repeat, must, find architectural expression. It is imperative that these works become cultural assets because they are part of our social life. Production of power - though their primary function - is not all that matters. ${ }^{28}$ Newman's projects played a role in the nationalistic propaganda programmes being fashioned by the government media machines, particularly the National Publicity Studio. Images graced newspapers, issues of Making New Zealand and The Weekly News; they formed the backdrop to summer barbecues, the destination of school trips. The mediating role of hydroelectric power stations, together with the state house, government office blocks, hospitals and primary schools, articulated for Newman the essential concern of architectural practice. The translation of public (read 'national' or 'social') necessity and values - established by politics and interpreted by policy - into built form was a primary concern of his department.

The Waikato River power scheme particularly moved Newman: 'Works, striking in their forms and of a strange but exciting rhythm, can at present be seen in some of the large hydro-electric constructions built by the Ministry of Works.' He saw in these power stations an 'amazing likeness to some of the monasteries built since the 10th century on the Greek islands in the Ægean Sea', specifically referring to Simopetra on Mount Athos. The restless and elemental images of the transformer platform and the penstocks inscribed with the lines of scaffolding and incompletion, 'reminds us of the fantastic perspectives of the Piranesi Brothers [sic] conceived during the time of the Baroque in Italy'. ${ }^{29}$ These engineering elements could remain visible; their completion, necessary for the station to function, would hide the historical allusions Newman understood to be operating in the stations. For Newman, the relationship between architects and engineers in public works projects was a fundamental issue in the practice of contemporary architecture. His essays, 'The Interrelation of Engineering Design and Architecture' and 'Architecture in Hydro Design', celebrate the complexities. ${ }^{30} \mathrm{He}$ shared the position of Le Corbusier's Versune architecture, ${ }^{31}$ that the engineering professional was making a stronger contribution to the built environment than architecture, and, like Le Corbusier, felt pressed to draw this to the attention of his colleagues. The 'sister profession' made progress possible, but the interaction of engineering design with architecture imbued any project with the credentials necessary to be 'sold' to the nation. 'The application of architectural elements - however skilfully scale, rhythm, proportions, etc., may be used - is not Architecture. Neither can lasting results be achieved if engineers and architects try individually or collectively to solve a problem only by analysis of and compliance with 
the functions of a structure. Nor is there any reason to expect a design of high quality, in the true sense of the word, by computation alone.' ${ }^{32}$ He went on: 'Tendencies, which exist in both camps, to oppose this cooperation, can only lead to cultural as well as material retrogression'. ${ }^{33}$ Newman recognised, in the negotiation of engineering and architecture as professions, a disciplinary responsibility of architecture to communicate the importance of public projects to social life. This he reinforced in each lecture and essay.

In setting out the parameters of the architect's influence in the public works programme, Newman considered the skills and attitudes an architect could constructively contribute to an engineer's work. As in the design offices of the Tennessee Valley Authority, Newman's architects enjoyed an open exchange with engineering design staff. The Hydro Design Office projects were unavoidably entrenched in engineering design issues; this was a necessary matter of expertise. However, in Newman's view, 'the problem in this type of work is to find a common platform or way of thinking between the Engineer and the Architect'. ${ }^{34} \mathrm{He}$ determined two fields in which architecture could operate successfully and effectively. Obviously, the buildings associated with the dams - turbine halls, offices, control facilities, workshops, and so on - belonged to his immediate field of concern. Simple determinants of function and circulation directly influenced planning, and a consultative process was involved to produce architectural products sensitive to the 'technological requirements of gear and power reticulation'. Referring to the design of powerhouse buildings, he noted that: 'The case is a problem of scale and order similar to the large single roomed edifices of the past, but restricted to engineering structures, site, etc. ${ }^{35}$ The speed with which the hydroelectric programme was being pushed forward demanded structures simply and quickly assembled on site. In comparison with the civil engineering costs of earthworks and dam construction and alongside electrical engineering expenses, the architectural budget was insignificant; however, as a stand-alone operational budget it was generous, allowing architects serious flexibility and experimentation in both their design work and their choices of materials.

For Newman, an architect's singular role was much less the design of discrete buildings or spaces than as a collaborator with other professionals in the design team. As engineering solutions developed into aesthetic decisions, the architect became responsible for resolving these decisions in the built form, and preparing it as a spectacle for national consumption via media mechanisms. In this sense, the addition of beauty to structure was fundamentally important. In a 1961 publication he wrote: 'However much an architect may have succeeded in producing a sound building satisfying all the requirements of his client, the ensuing work will contribute little to 
raise the status of the profession. The general public can only perceive the visual, and in the visual the emotional content is paramount. ${ }^{36}$ Newman's 1952 essay 'Social Factors in Architecture and Their Implications for New Zealand' included images of Alexander Vesnin's powerhouse of the Dneproges Project in the Soviet Union, describing it as '[one] of the outstanding examples of contemporary industrial design'. Praising the perfect application of the elements of architecture ('The room behind this impressive wall must be very beautiful') he ventured to ask: 'Is it not the transition into architecture of ideas on electrification and industrialisation?' ${ }^{37}$ Newman clearly read this hydroelectric project in terms of its synthesis of electricity and industrialisation within architecture. The role of the architect in multidisciplinary design teams thus afforded Newman with another dimension to his existing experience of architecture's social function. The responsibilities of architecture towards the public by means of visual treatment became, in terms of Newman's reuvre, another dimension of the architect's socially defined responsibilities.

\section{Social Factors in Architecture}

Although it was not published until 1952, Newman presented 'Social Factors in Architecture and their Implications for New Zealand' as a lecture to the Royal Society of New Zealand in August 1945. The text essentially articulates a set of principles for the judgement of good architecture. Illustrated by twenty-four examples, it includes, besides Vesnin's power station, Frank Lloyd Wright's Fallingwater, Le Corbusier's Villa in Garches, the Palace of the League of Nations in Geneva, the Cathedral at Limoges, Mendelsohn's University Medical Centre in Jerusalem, and the Caryatids adorning the Erechtheon upon the Acropolis. It suggests an international, though unconventional, architectural canon. Two New Zealand projects also make his list. Of the first, a building at Waiho (Turnbull and Rule), he writes: 'Why are so many architects of this country not searching in this direction instead of imitating buildings overseas which are mostly unsuited to this country in any respect, social as well as technical?' ${ }^{38}$ The British Residency at Waitangi ('one of the best examples of New Zealand architecture') likewise offers local architects a fitting model: 'This building is not only full of tradition but is also outstanding for its original architectural treatment and beautiful proportions' ${ }^{39}$ Erased from the final version of the analysis is the comment: 'New Zealand could develop its own domestic architecture without excessive overseas influence'. ${ }^{40}$ $\mathrm{He}$ concludes the essay with a reflection entitled 'Implications for New Zealand'. This critiques New Zealand architecture for its youthful lack of individual awareness: 'It is the social and cultural duty of everybody engaging in building, private or public, to see that the work becomes a 
cultural asset to the country, and not to economise on everything which, though beautiful, is of no direct material use'. ${ }^{41}$

The lessons implicit in 'Social Factors' remain almost unchanged over the seven years separating its two basic editions, but Newman's minor adjustments to the second index changes to New Zealand society, and in particular to the popular reception of such socialist messages as those earlier espoused by Lee. The Labour Government that had won the 1938 election with over half the votes cast failed to maintain its momentum, losing the 1949 general election to the conservative National Party. Industrial action during the post-War period culminated in the 1951 waterfront workers strike, prompting a snap election. The results of this election - again a National victory - revealed a significant shift in the political preferences of the New Zealand population towards the right. Left-wing politics aligned in the public eye with the communism of the Eastern Bloc nations. Whatever Newman's disillusionment from his time in Moscow, this did not prevent him from admiring the architectural achievements of the post-revolutionary period. Illustrating Soviet responses to the social factors in architecture, though, became a more contentious basis for Newman's advocacy for socially responsible practice.

The 1945 edition of the essay, which was merely annotated for printing in 1952, begins with a disclaimer: 'Experience gained by working in native Austria, in France, in Soviet Russia and now in New Zealand has been of great value in analysing the issues involved. Several examples are taken from today's Russia. There is no political intention whatsoever in this procedure. The references are necessary to make the case clearer. ${ }^{342}$ These sentences disappear from the 1952 edition. Their fate is shared by two passages from the essay's introduction:

A good example of how deeply such material considerations may influence the design is the rights of ownership of land in Russia, as compared with any other country in the world. There, the architect is not restricted by economic intricacies in respect of the best use of the land to procure the greatest profit to the owner. In very many cases that means that the Russian architect has more possibilities of composition than his colleagues in other countries. By using deeply recessed front courts, colonnades and other architectural features, he will reduce the area actually covered by the building in a way which would definitely be uneconomical elsewhere. ${ }^{43}$

Further:

The USSR is an example where a country at least claims to hold a leading idea and exhorts its architects to communicate the political and social ideals of present day Russia to the people. ${ }^{44}$ 
The former paragraph is replaced in the second version by an abstract communication of the same message, the first sentence truncated to read simply: 'A good example of how deeply such material considerations may influence the design is the rights of ownership of land. ${ }^{35}$ Russophile hints have been systematically erased. Where the message is inextricable from the example, as in the second cited paragraph, it is simply deleted. This fate is shared by a number of specific examples. A block of flats by Shoussev for the Institute of Soviet Architect, on the banks of the Moskwa River, celebrates the 'national art' of Russia: 'Architects are considered very desirable and important contributors to Russian culture. They therefore deserve the best type of building the country can offer them. Hence the monumentality of the design and the lavish finish. ${ }^{46}$ In Shoussev's Theatre of the Red Army in Moscow: 'the architect has certainly been given all the necessary means to show in this building the might and glory of the famous Red Army and has used these means wisely'. ${ }^{47}$ Presenting the Theatre Meyerhold in Moscow, Newman reflects on the 'Habima' (a 'similar group of artists'), about whom Lenin said 'if the revolution had only served to free these artists from repression, it would not have been in vain'. ${ }^{48}$ The New York headquarters of the United Nations stays, too good an example of both Lewis Mumford's axiom 'Starvation in the midst of plenty' and Henry Miller's 'Air Conditioned Nightmare'. ${ }^{49}$ Yet gone is a flourmill and silos, as well as an aluminium factory, both by Shernikov, along with the recommendation of industrialisation: "Industrialisation in the period of reconstruction decides all." This was the main political slogan for the 180 million people living in Russia in the prewar period. The events of this war have shown the truth of this slogan not only for the USSR but for the whole world. ${ }^{50}$ Vesnin's Dneproges powerhouse shifts from being 'the translation into architecture of the ideas of today's Russia on electrification and industrialisation' to the less specific 'translation' cited earlier. ${ }^{51}$ Even the reconstruction of Moscow is sidelined, the 'political and emotional factors' expressed in the plan too clearly expressing the 'political idea of making Moscow the cultural and government centre of Russia. ${ }^{52}$

Yet it is not simply in the relevance of communist architectures to postWorld War Two New Zealand that Newman's redraft of 'Social Factors in Architecture' gives us pause. The 'wonderful results' achieved by 'the gigantic task of colonisation' in New Zealand is balanced by Newman with a concern for Maori architectural culture: 'Architectural education will have to step in to achieve this essential link with the past and also to bring Maori art and people more fully into the artistic life of the country; not to imitate ornament but to absorb their great and wonderful tradition. Have we got Maori architects? It does not seem so. They certainly would contribute if properly trained. ${ }^{53}$ That Newman erased this passage in 
preparation for the published edition of 'Social Factors' reveals some of the biases generally held against Maori architectural traditions in those years. It further signals the extent to which Newman was searching out a local context to test his ideas on architecture's social responsibility. The attitude of the local profession towards Maori architects was clearly far from mature in Newman's eyes.

'Social Factors in Architecture' is a significant reflection on New Zealand's post-1945 architectural culture, describing in terms of architectural polemics the dramatic shift from the left-wing concerns of the 1930s and 40s to the public fear of things communist rapidly taking hold in the early 1950s. Set beside Newman's technically orientated writing on the architect's role in engineering works, the text describes the field of architectural precedents informing his practice within the Ministry of Works, diffused in turn within the values of the architects who worked for Newman in the Hydro Design Office during the period 1948-1956. It is further important as a precursor to the question of housing, which consumed the remainder of his public service career.

\section{Housing Architect}

Appointed the Ministry of Works' Housing Architect in 1956, Newman turned his thinking to the question of medium-density accommodation. His 1957 essay 'Housing Design' called for a rigorous reappraisal of domestic life, expressing a concern for the modernisation of New Zealand from both architectural and economic perspectives. Newman observed that Victorian conventions continued to dictate the planning of domestic space, that singledetached dwellings were non-negotiable

\section{F.H. Newman (pictured left) on site, c.1957.}

Source: Newman family

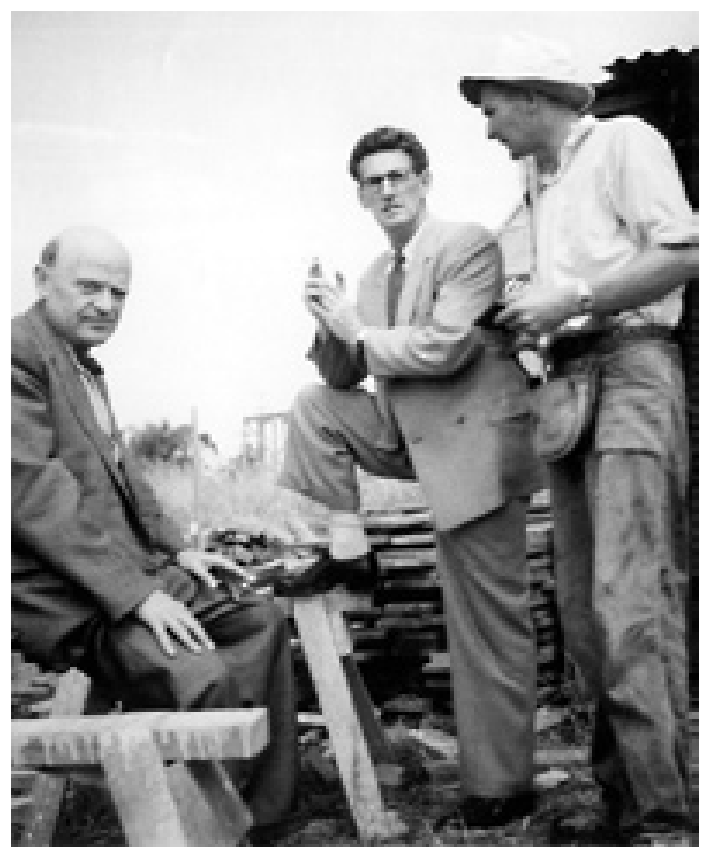


accommodation solutions and that timber inevitably triumphed over concrete and steel, etc. These were, he perceived, symptoms of a general reluctance to accept the nature of modern life. While he praised a number of individuals for their attempts to address these issues, he observed a lethargic Victorian mentality within housing policy, a reflection of nineteenth century attitudes towards domestic inhabitation throughout society.

As Housing Architect, Newman sought to meet needs on two levels: low cost strategies for home ownership and socially responsive proposals for medium- and high-density rental accommodation. With the return of a Labour Government in 1957, the Ministry of Works proposed alternatives to National's programmes of individual home ownership: 'How can the home builder with modest resources and a small section build an economical house containing sufficient accommodation for his immediate needs in such a way that low-cost additions can be made later on without upsetting the plan?'54 Newman's proposal for 'expanding houses' - small houses with systematic renovations programmed into their design - responded to the problems of property ownership in a society where that ownership was contingent on land possession in addition to building. The appearance of the State house shifted dramatically from this time, Newman himself explaining: 'the usual appearance of State houses . . . has remained the same for a considerable period. The Minister of Housing asked for a change in the architectural concept. ${ }^{55}$ The appearance of State houses, believed Newman, inappropriately indexed Victorian New Zealand values within a twentieth-century economic context. As he declared in a 1959 lecture to the Royal Society of New Zealand: 'The pattern was simply to design a combination of smaller rooms in the traditional way in order to provide a greater number of houses for the same amount of money'. ${ }^{56}$ Newman's proposals shifted this focus to allow buildings to respond to the immediate needs of the family: 'Only lately this approach has changed to something where one can recognise an attempt to express a new way of life. ${ }^{57}$

Newman developed several housing models in response to the perceived new way of life. Expanding Houses could start as two-bedroom buildings, growing vertically and laterally if or when necessary. Flats for Single People, Two Unit Corner Flats, Multi Units, Cross Over Flats, Ten Units Flats, Duplex Flats, Atrium Flats and Units on Sloping Sites were each proposed as accommodation solutions that mixed the need for personal privacy with the imperative to save on land and to halt suburban sprawl. The Star Flats also date from this time, providing a model for medium-sized communities of families operating from a single building. Newman's projects, however, conceived with a strong social agenda at heart, were regularly undermined in the course of their implementation by housing authorities. Carefully calculated densities doubled or tripled, housing demand flattening plans to 


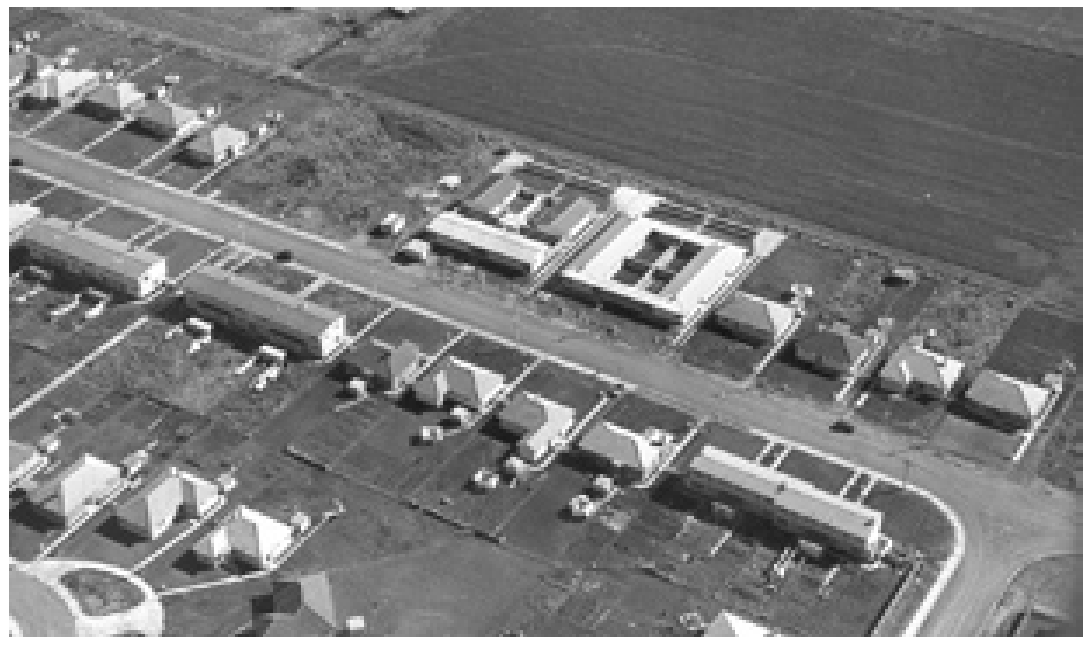

Photo: F.H. Newman. Source: Newman family

Atrium Flats (surrounded by single detached State houses), Dunedin, Ministry of Works (F.H. Newman, Sectional Architect), 1946-1953.

accommodate mixed demographics, rendering the buildings unsuccessful as long-term social experiments.

Newman nevertheless continued to look to Europe for his inspiration. From February to August 1960, he undertook an overseas research trip in his capacity as Housing Architect. He travelled in search of the most contemporary solutions to the new problems arising from increasing density in urban populations. In his application for leave to travel overseas, Newman wrote:

The [Housing] Division has been fortunate to effect substantial savings by the use of these new types which were on a whole very favourably received by the people living in them. There is however one aspect that causes some concern. The introduction of medium density housing on a substantial scale is obviously changing the living habits of a section of the population. Though the designs prepared by the Housing Division are generally considered the very best possible under the circumstances, it would be very important to investigate at this particular stage the position in other countries. Such a study may very well result in some new approach. ${ }^{58}$

The outcome of this application was a study visit to England (21 days), France (13 days), Switzerland (1 $1 \frac{1}{2}$ days), Italy (59 days) and Austria (12 days). England and Italy formed a particularly important part of Newman's investigations. While England continued to be a model for New Zealand 
in all areas of life, Italy was more confidently trialling new approaches to housing design.

Of England, Newman noted: 'Though conditions . . . are by no means the same as in New Zealand, architects in both countries do attempt to preserve as much as possible the English mode of living, with its emphasis upon respect for the privacy of the individual'.$^{59}$ To this end, he considered three responses to the problem of the 'English mode of living': London County Council housing projects, New Towns (illustrated by Stevenage), and private housing. In a discussion with 'some prominent university people while staying in the British School of Rome . . . the consensus of opinion was that the striving for privacy developed only in the last century with the advent of "suburbia" and was of little importance for the English way of life in earlier days. I recommend a small scale experiment of "closed" development because of the saving of land inherent to such a scheme. ${ }^{60}$ This analysis reinforced the steps he had already taken within New Zealand to develop medium density housing types, in particular by means of the Atrium Flats.

Newman's diary entries reveal the development of an interesting professional relationship with the Italian housing authorities. In Rome, Newman attended an evening meeting of the Instituto nazionale [dell]'architettura [Ina] at the invitation of its secretary, de Rosi. There he met the director of Ina-casa, Renato Bonelli, and Bruno Zevi, professor and editor of Casabella-continuità, also hearing a lecture by the engineer Pier Luigi Nervi. Two days later, he met with Bonelli at the Ina-casa to discuss the financing of Italian state housing. The following week, Newman lectured at Ina on the development of New Zealand housing from Victorian times to the present day. Bonelli encouraged him to 'keep in touch with this organisation so that an exchange of ideas can be continued'. ${ }^{61}$ A letter prepared for Bonelli with Newman's 'critical impressions concerning the architectural work of Ina-casa' commenced the exchange. Besides some detailed suggestions for economical approaches to space planning, Newman wrote: 'I have great pleasure in telling you that I was greatly impressed with the general layout, detail planning and architectural appearance of the buildings'. ${ }^{62}$

Newman published his reflections on his continental investigations in the essay 'The Architect's Design and His Status'. In it, he advanced the lesson of his experiences in the Hydro Design Office, that the architect has the capacity to bridge social responsibility and the cultural life of a community by concentration on the visual aspects of design work:

My studies in England, France and particularly in Italy have convinced me that among the many factors influencing the status of the architect, the visual aspect of our designs has a very special and, I dare to say, 
decisive place. Though this is by no means a new discovery it seems that in our time this matter has not been given the prominence it deserves and did enjoy in past periods. This is the reason which has tempted me to explore this particular field again and to present a paper on the subject. ${ }^{63}$

Newman never lost faith that the New Zealand architectural profession would reach a more empathetic relationship with the society it was charged to serve. Only in such a setting could the reconciliation of the greater public good with the needs of individuals be addressed. In 1959 he wrote:

We have reached the stage when for the first time in New Zealand's history significant changes in many buildings are discernible. Before us lies an open road [down] which we must go, so that the future generations can look back to the present period as the time when the ideals of a new society were first expressed by way of [a] better physical environment and beautiful buildings. ${ }^{64}$

In Newman's conception of the role of the profession in social life, great potential lay in the field of communication. 'How often is it said that the public needs education?' he wrote, 'Perhaps we ourselves need a better understanding of society, in case we struggle to give it unsuitable buildings and spaces' ${ }^{65}$ The integrity of architecture as a social art relies on architecture moving 'more consciously . . . into the field of communication'. ${ }^{66}$ That field engages 'not only the emotions of everyday life, but also those sublime feelings which are closely linked with the social ideals of a people' ${ }^{67}$ The ideologically driven architecture of Vienna and the Soviet Union outlived beliefs that diminished with changing political tides. Newman saw in New Zealand a chance to realise architecture that would capture the basic values already expressed by his adopted society through its day-to-day life, but not in architecture. This project was deeply personal to Newman, reflecting a lifetime's thinking on the question of architecture's role as a public and therefore social art. The instruments he engaged were public works realised with public funds. They were important responses to the serious issues of electrification, industrialisation, and increased basic living and housing standards. By introducing Newman's polemics as a setting for his architectural production, this essay celebrates a personal complexity beyond the analysis of official records from Ministry of Works architectural agencies.

1 This essay expands on papers previously presented at the Stout Research Centre for New Zealand Studies, 17 October 2001, and to the conference 'Displacement and Creativity: Refugees and the Arts in New Zealand,' University of Auckland, 5 September 2001. 


\section{Journal of New Zealand Studies}

2 In deference to Newman's decision to anglicise his name after arriving in New Zealand, I call him 'Neumann' with reference to events before 1947 and 'Newman' subsequently.

3 Pers. comm. Leslie Lipson (a family friend of the Neumanns) to Andrew Leach, 9 September 1999.

4 These projects represent mainstream beaux-arts design concerns: a preoccupation with movement through space, the 'reward' of the stage, the performance of the building. The following projects are represented: the Vienna Volkstheater, the Budapest Variety Theatre (subsequently destroyed by fire during World War Two), the town theatres of (in Austria) Ravensburg (plus another theatre and concert house) and Salzburg (plus the Mozart Festspielhaus and a second theatre); (in Hungary) Budapest, Kecskemét (the Jozseph Katona Theatre) and Épitkezés town theatres; in Romania, Nagyváradi town theatre; in Poland, Bielsko-Biala (formerly Bielitz-Biala) town theatre.

5 Ernst von Gotthilf and Alexander Neumann, Ernst von Gotthilf, Vienna: 1915, Wiener Bank-verein, Vienna: 1912.

6 On this competition and its subsequent controversy see the following: John Ritter, 'World Parliament: The League of Nations Competition, 1926', Architectural Review, vol. 136, July 1964, pp.17-23; Kenneth Frampton, 'The League of Nations, the Centrosoyus and the Palace of the Soviets, 1926-31', AD, vol. 55, nos. 7-8, 1985, pp.41-54.

7 Manfredo Tafuri, "'Red Vienna": Housing Policy in a Socialist City', Tafuri and Francesco Dal Co, Modern Architecture, vol. 1, trans. Robert Erich Wolf, 1976, New York: Rizzoli, 1986, p.162.

8 On 'Red Vienna', see also Manfredo Tafuri, Vienna Rossa: La politica residenziale nella Vienna socialista, Milan, 1980 and Eve Blau, The Architecture of Red Vienna, Cambridge and London, 1999.

9 Tafuri, "Red Vienna", pp.162-164.

10 'Zeugnis [Testimony]' [German] 1 March 1930 and 27 February 1931 (Collection of F.H. Newman).

11 Tafuri, "Red Vienna", p.166.

12 'Vertrag [Contract],' [German and Russian] 26 January 1932 (Collection of F.H. Newman).

13 Tafuri, "Red Vienna", p.190.

14 Correspondence F.H. Neumann to Department of Passports, 21 May 1938 (Collection of F.H. Newman). The letter continues: 'We apply for the grant of the exit-and-return visa, obliging ourselves at the same time, to return never to Germany for permanent residence.'

15 Correspondence A. Tyndall to F. Neumann, 17 August 1938 and 10 February 1939 (Collection of F.H. Newman).

16 Julia Gatley, 'Labour Takes Command: A History and Analysis of State Rental Flats in New Zealand, 1935-1949', MArch thesis, Victoria University of Wellington, 1997, p.179, 201.

17 C. R. Attlee, 'Introduction' to John A. Lee, Socialism in New Zealand, London, 1938, p. v.

18 Ibid., p.vi.

19 Lee, Socialism in New Zealand, p.8.

20 Ibid., p.285.

21 The Politics of Equality: New Zealand's Adventures in Democracy, Chicago, 1948.

22 Neumann, 'A Moral Approach to Social Order,' p.1 (Collection of F.H. Newman).

23 Ibid., pp.1-2.

24 Ibid., pp.6-8.

25 Pers. comm. Lipson to Leach, 9 September 1999, p.2 
26 Incidentally, John A. Lee also noted this in Socialism in New Zealand: 'Lenin saw more clearly than he knew when he saw electrification rather than ideology as socialism. In this power age, New Zealand has an adventurous socialist idealism, and if that idealism utilizes the unparalleled power resources of the country, time for more than material production is at hand. The only vested interest to throw down in the electrical sphere is per cent interest, which is, after all, not indigenous but exotic in the southern seas. The southern mountains will comb the water out of the winds and the skies. Steep gorges will speed the waters and high dams will bridle the torrents, and in a power age of all material civilisations the New Zealand socialist one shall be the richest to incredibility.' - Lee, op. cit., p.122.

27 Design Review, vol. 4, no. 4, August/September 1952, pp.88-89.

28 F.H. Newman, 'Architecture in Hydro Design', Journal of the New Zealand Institute of Architects, vol. 26, no. 3, April 1959, p.81.

29 F.H. Newman, 'Beauty in Engineering', p.88.

30 F.H. Newman, 'Interrelationship of Engineering Design and Architecture', Journal of the New Zealand Institute of Architects, vol. 18, no. 6, July 1951:, pp.93-108.

31 Le Corbusier, Vers une architecture, Paris, 1923.

32 F.H. Newman, 'Interrelationship of Engineering Design and Architecture', p.95.

33 Ibid., p.96.

34 F.H. Newman, Unpublished Exhibition Notes, Hydroelectric Design, Ministry of Works, c.1956, unpaginated (Collection of F.H. Newman).

35 Ibid., Exhibition Notes.

36 F.H. Newman, The Architect's Design and His Status: Comments on a Visit to England, France, and Italy, Wellington, 1961, p.22.

37 F.H. Newman, Social Factors in Architecture and their Implications for New Zealand, Wellington, 1952, p.16.

38 Ibid., p.12.

39 Ibid., p.15.

40 F.H. Newman, 'Social Factors in Architecture and Their Implications for New Zealand [manuscript]', 1945, p.27 [orig. p.29], (Collection of F.H. Newman).

41 F.H. Newman, Social Factors in Architecture, p.18.

42 F.H. Newman, 'Social Factors in Architecture [m/s]', preface.

43 Ibid., p.2.

44 Ibid., p.2.

45 F.H. Newman, Social Factors in Architecture, p.3.

46 Ibid., p.24.

47 Ibid., p.25.

48 Ibid., p.23 [p.26].

49 Ibid., p.24 [p.27].

50 Ibid., pp.31-32.

51 Ibid., p.30 [p.33].

52 Ibid., pp.35-36 [p.32].

53 Ibid., p.33 [p.37].

54 Ministry of Works Housing Division (F.H. Newman, Housing Architect), 'Expanding Houses: Parade of Homes, 1957', p.5.

55 Ibid., p.7.

56 F.H. Newman, 'New Zealand Housing in the Light of an Expanding Society', unpublished paper presented to the Royal Society of New Zealand, Wellington, 15 September 1959, p.1 (Collection of F.H. Newman).

57 Ibid., p.1. 


\section{Journal of New Zealand Studies}

58 F.H. Newman, 'Report on Overseas Investigations 5.2.1960 - 31.8.1960,', [MoW ref.: H.C. 3/1/1/5, 25 November 1960], covering letter, extract from Letter of Application, 28 October 1958 (Collection of F.H. Newman).

59 Ibid., p.1.

60 Ibid., pp.5-6.

61 Ibid., p.16.

62 Ibid., pt. I, p.9.

63 F.H. Newman, The Architect's Design and His Status, Wellington, 1961, p.3.

64 F.H. Newman, 'New Zealand Housing in the Light of an Expanding Society', p.4.

65 F.H. Newman, 'Design', unpublished manuscript, c.1963, p.1 (Collection of F.H. Newman).

66 Ibid., p.2.

67 F.H. Newman, 'Social Factors in Architecture and their Implications for New Zealand', manuscript, 1952, ref. W004 (Collection of F.H. Newman), p.1. 